\title{
Recovery from episodic acidification delayed by drought and high sea salt deposition
}

\author{
H. Laudon \\ Department of Ecology and Environmental Sciences, Umeå University, 90187 Umeå, Sweden
}

Received: 31 October 2006 - Published in Hydrol. Earth Syst. Sci. Discuss.: 11 September 2007

Revised: 28 November 2007 - Accepted: 5 February 2008 - Published: 5 March 2008

\begin{abstract}
For the prediction of episodic acidification large uncertainties are connected to climatic variability and its effect on drought conditions and sea-salt episodes. In this study data on 342 hydrological episodes in 25 Swedish streams, sampled over 10 years, have been analyzed using a recently developed episode model. The results demonstrate that drought is the most important factor modulating the magnitude of the anthropogenic influence on $\mathrm{pH}$ and ANC during episodes. These modulating effects are especially pronounced in southern and central Sweden, where the historically high acid deposition has resulted in significant $\mathrm{S}$ pools in catchment soils. The results also suggest that the effects of episodic acidification are becoming less severe in many streams, but this amelioration is less clear in coastal streams subject to high levels of sea-salt deposition. Concurrently with the amelioration of the effects of episodic acidification, regional climate models predict that temperatures will increase in Sweden during the coming decades, accompanied by reductions in summer precipitation and more frequent storms during fall and winter in large areas of the country. If these predictions are realized delays in streams' recovery from episodic acidification events can be expected.
\end{abstract}

\section{Introduction}

A steady but slow recovery from acidification is occurring in many surface waters in Europe and North America due to reduction in anthropogenic acid deposition (Skjelkvåle et al., 2001; Stoddard et al., 1999). These findings have been based on assessments that have focused mainly on changes in annual mean values of $\mathrm{pH}$ and Acid Neutralization Capacity (ANC). Although the documented improvements are important, the ecological significance of these trends has been dif-

Correspondence to: H. Laudon

(hjalmar.laudon@emg.umu.se) ficult to assess in many places because the aquatic biodiversity is as much or more affected by transient declines in $\mathrm{pH}$ and ANC associated with snow melt and rain episodes than long-term mean values of stream water chemistry (Baker et al., 1996; Kowalik and Ormerod, 2006; Lepori et al., 2003). While surface waters in Europe and North America are recovering from chronic acidification (Raddum et al., 2001; Yan et al., 2004), severe episodic acidification may continue to threaten sensitive biota in many regions.

Although much work has focused on identifying the causes and effects of episodic acidification in recent decades, the role of confounding factors is less well understood. In order to predict the effects of future transient acidification events some of the most important uncertainties that need to be addressed are those mediated by drought and sea-salt episodes, which may in turn be strongly affected by climatic change. Summer droughts in humid glaciated regions are known to lower the water table of wetlands, thereby causing conditions suitable for the re-oxidation of previously reduced compounds. In areas with historically high levels of acid deposition, hydrological events following these dry periods can result in pulses of acidic, $\mathrm{SO}_{4}^{2-}$-rich water entering streams (Christophersen et al., 1983; Devito et al., 1999; Eimers et al., 2004a). Sea-salt episodes occur due to cation exchange processes in the soil, mainly involving exchange of $\mathrm{Na}^{+}$with acidifying $\mathrm{H}^{+}$and Al-cations, while $\mathrm{Cl}^{-}$acts as a mobile anion and passes through the soil relatively unaltered (Heath et al., 1992; Neal and Kirchner, 2000). Sea-salt deposition associated with severe storm conditions therefore can transiently increase the acidification effects by mobilizing acid cations that are subsequently transported to streams. Predictions of climate-change effects in Europe suggest that future conditions will be drier in some regions, and storm frequencies will increase in others (Kjellström, 2004). Thus, anticipated climatic changes may have significant effects on seasalt episodes, drought conditions, and associated responses of stream water chemistry, but the magnitude of these likely

Published by Copernicus Publications on behalf of the European Geosciences Union. 


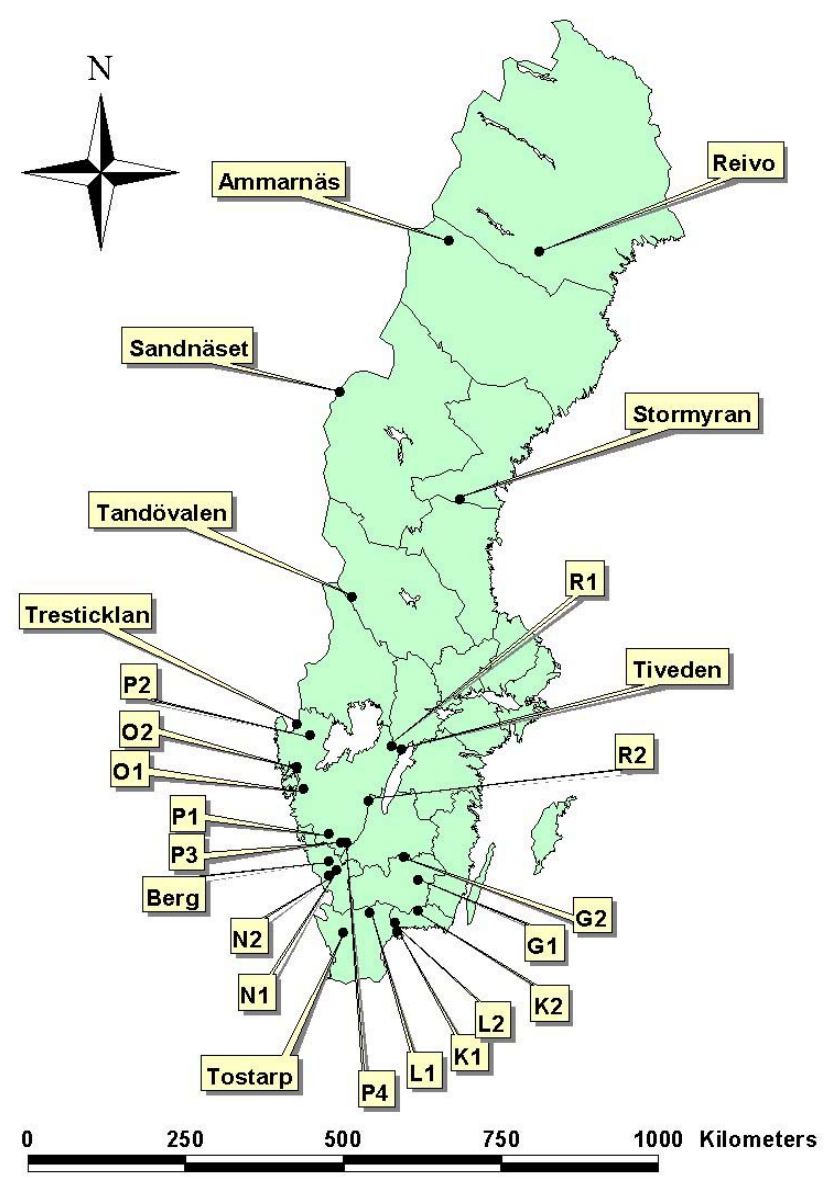

Fig. 1. Map showing the locations of the studied streams in Sweden.

effects, and their interactions with the ongoing decline in the effects of anthropogenic acidification, warrants further investigation.

Because of the stochastic and transient nature of episodic acidification events, they have not received the same attention as chronic acidification. With a few exceptions (Laudon et al., 2002; Laudon and Hemond, 2002; Lawrence, 2002) long-term assessments of episodic stream water chemistry trends have been constrained by data availability. Most previous work on episodic acidification has focused on shortterm time series lasting only a few years (Wigington et al., 1996). Therefore it has often been difficult to assess whether the long-term decline in acid depositions has resulted solely in improvements in annual average values, or whether it has also ameliorated the effects of episodic acidification. The lack of long-term studies also makes it difficult to discern if temporal changes observed in the intensity of episodic $\mathrm{pH}$ and ANC declines are caused by inherent variability in the episodic responses, changes in rates of acid deposition or natural climatic variability.

The objective of this study was to assess whether the longterm decline in acid deposition has ameliorated the effects of episodic acidification in a number of small streams in Sweden monitored over 10 years. In total, data related to 342 hydrological episodes from 25 streams have been analyzed in an attempt to separate the responses to anthropogenic acidification in surface water chemistry from natural variability during summer and fall episodes using the Boreal Dilution Model (BDM; Bishop et al., 2000; Laudon et al., 2001).

\section{Study region and data}

The data analyzed in the study consist of measurements acquired during the course of 342 hydrological episodes in 25 Swedish streams (Fig. 1; Table 1). The catchments of these streams are located along a climate and deposition gradient, across which mean annual temperatures and precipitation vary from +7 and $>1000 \mathrm{~mm}$, respectively, in the southern parts of the country, to $-3^{\circ} \mathrm{C}$ and $600 \mathrm{~mm}$ in the northern parts of the country. Of the 25 streams, 16 are located in southern Sweden, four in central Sweden and five in northern Sweden. The separation of the catchments into regions is based on both geography and acid deposition history. Open-field rates of deposition of sulfur and nitrogen compounds in Sweden ranged from 2 to $15 \mathrm{~kg} \mathrm{Sha}^{-1}$ year $^{-1}$ and 2 to $10 \mathrm{~kg} \mathrm{Nha}^{-1}$ year $^{-1}$, respectively, during the late 1990's (Kindbom et al., 1998), decreasing from both west to east and from south to north. Hence, the highest deposition loads of acidifying compounds occurred in southern Sweden $\left(>7 \mathrm{~kg} \mathrm{Sha}^{-1}\right.$ year $\left.^{-1}\right)$ followed by central Sweden $\left(3-5 \mathrm{~kg} \mathrm{Sha}^{-1}\right.$ year $\left.^{-1}\right)$ and northern Sweden $\left(<3 \mathrm{~kg} \mathrm{Sha}^{-1}\right.$ year $\left.^{-1}\right)$ (Table 1). Sulfur deposition has been decreasing at a steady rate since 1970 (Mylona, 1996), while nitrogen deposition has remained constant since the beginning of the 1990's (Warfvinge and Bertills, 2000).

The streams, all drain forested catchments varying from 2 to 1090 ha in size, and have been included in two national sampling programs: the PMK network program funded by the Swedish EPA, and the Skokal network program funded by the Swedish Forest Agency. No major forestry activities have been undertaken in any of the catchments in recent decades (Folster and Wilander, 2002).

All the streams have been sampled weekly to monthly, with varying sampling frequency over time. The samples obtained have been analyzed at the Department of Environmental Assessment, Swedish University of Agricultural Sciences, Sweden. All streams have been sampled during at least a 10year period, starting between 1985 and 1990. Rather than analyzing the same time period for all streams, the time series were kept as long as possible to enable trend assessments of episodic acidification in the individual streams. Chemical analyses were performed by certified laboratories according to EN or ISO standards where applicable (Wilander et al., 1998). Un-aerated samples were used for the $\mathrm{pH}$ measurements, immediately after sampling. Analyses of $\mathrm{Ca}, \mathrm{Mg}, \mathrm{Na}$ and $\mathrm{K}$ were measured using inductively coupled 
Table 1. Summary of catchment characteristics.

\begin{tabular}{lcccccc}
\hline Stream & Year & $\begin{array}{c}\text { Catchment } \\
\text { size (ha) }\end{array}$ & $\begin{array}{c}\mathrm{N} \\
\text { Episodes }\end{array}$ & $\begin{array}{c}\text { Deposition } \\
\left(\mathrm{Kg} \mathrm{S} \mathrm{ha}^{-1} \mathrm{yr}^{-1}\right)\end{array}$ & $\begin{array}{c}\Delta \mathrm{ANC}_{\text {(poll) }} \text { vs. Q } \\
(\mathrm{p} \text {-value) }\end{array}$ & $\begin{array}{c}\Delta \mathrm{ANC}_{\text {(poll) vs. year }} \\
\text { (p-value) }\end{array}$ \\
\hline Southern Sweden & & & & & & \\
G1 (4) & $1991-2001$ & 275 & 13 & $5-7$ & 0.001 & 0.04 \\
G2 (4) & $1991-2001$ & 125 & 13 & $5-7$ & 0.04 & 0.05 \\
G2 (4R) & $1991-2001$ & 179 & 14 & $5-7$ & 0.01 & 0.04 \\
K2 (4) & $1991-2001$ & 157 & 11 & $5-7$ & 0.02 & N.S. \\
L1 (4) & $1990-2000$ & 41 & 12 & $8-9$ & 0.02 & 0.05 \\
L2 (4) & $1990-2000$ & 92 & 11 & $5-7$ & N.S. & N.03 \\
O2 (4) & $1990-2000$ & 16 & 10 & $5-7$ & N.S. & N.S. \\
N1 (4) & $1990-1999$ & 12 & 10 & $10-15$ & 0.0007 & N.S. \\
P1 (4) & $1991-2000$ & 14 & 16 & $10-15$ & 0.0001 & 0.05 \\
P2 (4) & $1991-2001$ & 20 & 16 & $7-9$ & N.S. & 0.05 \\
P3 (4A) & $1991-2000$ & 2.2 & 10 & $10-15$ & 0.002 & 0.02 \\
P3 (4B) & $1991-2000$ & 4.0 & 11 & $10-15$ & 0.0008 & N.03 \\
R2 (4) & $1991-2000$ & 32 & 12 & $5-7$ & N.S. & N.S. \\
Berg (Pipbäcken N) & $1986-1995$ & 90 & 8 & $10-15$ & N.S. & N.S. \\
Berg (Pipbäcken Ö) & $1986-1995$ & 73 & 13 & $10-15$ & 0.04 & N.S. \\
Tostarp & $1985-2000$ & 170 & 13 & $10-15$ & 0.02 & 0.02 \\
Central Sweden & & & & & & N.S. \\
Tresticklan & $1985-2002$ & 140 & 25 & $3-5$ & 0.002 & N.S. \\
Tiveden (Bråtäng) & $1985-2002$ & 750 & 23 & $3-5$ & 0.01 & N.S. \\
Tiveden (Lomma N) & $1985-2002$ & 100 & 28 & $3-5$ & 0.03 & N.S. \\
Tiveden (Lomma Ö) & $1985-1996$ & 30 & 13 & $3-5$ & 0.08 & N.S. \\
Northern Sweden & & & & & & N.S. \\
Tandövalen & $1986-2000$ & 580 & 17 & $2-3$ & N.S. & N.S. \\
Stormyran & $1986-2002$ & 320 & 13 & $2-3$ & 0.03 & N.S. \\
Sandnäset & $1985-2002$ & 50 & 10 & $1-2$ & N.S. & N.S. \\
Ammarnäs & $1985-2002$ & 220 & 9 & $1-2$ & & \\
Reivo & $1985-2002$ & 1090 & 11 & $1-2$ & & \\
\hline
\end{tabular}

plasma-optical emission spectrometry (ICP-OES), while $\mathrm{Cl}^{-}$ and $\mathrm{SO}_{4}^{2-}$ were measured using ion chromatography. $\mathrm{NO}_{3}$ was analyzed using the cadmium reduction method with a segmented flow analyzer.

\section{Data analysis}

An episode is defined here as a 10-fold (or more) increase in discharge rate. Thus, the definition is based entirely on hydrology. Each hydrological episode was analyzed using the Boreal Dilution Model (BDM; Bishop et al., 2000; Laudon et al., 2001). This model has been used to quantitatively distinguish between natural and anthropogenic mechanisms underlying episodic declines of acid neutralising capacity (ANC) during both snow melt-driven hydrological episodes (Laudon and Hemond, 2002) and rain-driven episodes (Laudon and Bishop, 2002) in northern Sweden and during rain events in Canada (Laudon et al., 2002, 2004). The BDM identifies the anthropogenic component of episodic ANC decline $\left(\triangle \mathrm{ANC}_{(\mathrm{poll})}\right)$ from relative differences in the runoff dynam- ics of base cations and anthropogenic acid anions during hydrological events.

The BDM is based on the concept that the natural, preindustrial acid-base chemistry dynamics during episodes result primarily from dilution of the buffering capacity by low ionic strength precipitation (Bishop et al., 2000). The $\mathrm{BDM}$ is driven by the observed $\mathrm{ANC}\left(\mathrm{ANC}_{(\mathrm{obs}, t)}\right)$ at any time "t" during the flow event (Eq. 1) and a dilution in$\operatorname{dex}\left(\mathrm{DI}_{(t)}\right.$; Eq. 2), which is an estimate of the natural dilution of both $\mathrm{BC}$ and the anthropogenically significant anions of strong mineral acids (ANSA $\left.=\left(\mathrm{SO}_{4}^{2-}\right)+\left(\mathrm{NO}_{3}^{-}\right)\right)$. The sum of base cations $\left(\mathrm{BC}=\left(\mathrm{Ca}^{2+}\right)+\left(\mathrm{Mg}^{2+}\right)+\left(\mathrm{Na}^{+}\right)+\left(\mathrm{K}^{+}\right)\right)$is used in the determination of the DI (Eq. 2). The natural, preindustrial $\mathrm{ANC}\left(\mathrm{ANC}_{(\text {preind, } t)}\right)$ is calculated from the dilution of baseflow ANC $\left(\mathrm{ANC}_{(\text {base })}\right.$, Eq. 3). The difference between $\mathrm{ANC}_{(\text {preind, } t)}$ and the observed $\mathrm{ANC}_{(\mathrm{obs}, t)}$ represents the human influence on the ANC $\left(\triangle \mathrm{ANC}_{(\mathrm{poll}, t)}\right.$, Eq. 4$)$ during the episode. All concentrations are in $\mu \mathrm{eq} \mathrm{L}^{-1}$ of charge.

$$
\begin{aligned}
& \mathrm{ANC}_{(\mathrm{obs}, t)}= \\
& \left(\mathrm{Ca}^{2+}\right)_{(t)}+\left(\mathrm{Mg}^{2+}\right)_{(t)}+\left(\mathrm{Na}^{2+}\right)_{(t)}+\left(\mathrm{K}^{+}\right)_{(t)}-\left(\mathrm{SO}_{4}^{2-}\right)_{(t)}-
\end{aligned}
$$



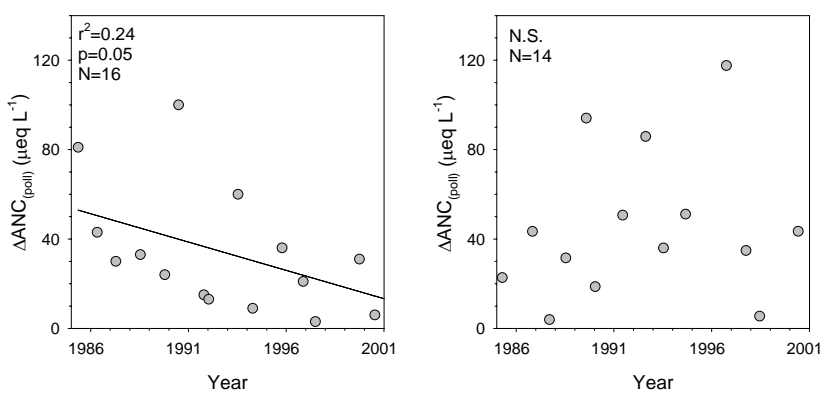

Fig. 2. Trend in anthropogenic response $\triangle \mathrm{ANC}_{(\text {poll })}$ during episodes in one inland stream (Bråtäng) with declining $\triangle \mathrm{ANC}_{(\mathrm{poll})}$ (left) and one coastal stream (Tostarp) with no trend in $\mathrm{ANC}_{(\text {poll })}$ over time (right).

$$
\begin{aligned}
& \left(\mathrm{NO}_{3}^{-}\right)_{(t)}-\left(\mathrm{Cl}^{-}\right)_{(t)}=\mathrm{BC}_{(t)}-\mathrm{ANSA}_{(t)}-\left(\mathrm{Cl}^{-}\right)_{(t)} \\
& \mathrm{DI}_{(t)}=\mathrm{BC}_{(t)} / \mathrm{BC}_{(\text {base })}
\end{aligned}
$$

$\mathrm{ANC}_{(\text {preind }, t)}=\mathrm{DI}_{(t)} *\left(\mathrm{BC}_{(\text {base })}-\mathrm{ANSA}_{(\text {base })}\right)-\left(\mathrm{Cl}^{-}\right)_{(t)}(3)$

$\Delta \mathrm{ANC}_{(\text {poll }, t)}=\mathrm{ANC}_{(\text {preind }, t)}-\mathrm{ANC}_{(\mathrm{obs}, t)}$

Organic acidity is not included in the ANC calculation as DOC has not been analyzed during the entire sampling period used in this study. The exclusion of the strong organic acid component from the ANC expression is the common procedure in international negotiation work in Europe (Posch et al., 1997). Furthermore, as the analyses of $\Delta \mathrm{ANC}_{(\mathrm{poll}, t)}$ is based on the relative difference between $\mathrm{ANC}_{(\text {preind, } t)}$ and $\mathrm{ANC}_{(\mathrm{obs}, t)}$ (Eq. 4) this simplification should not bias the results.

The assumptions and sensitivity of the model have been tested by Bishop et al. (2000) and Laudon et al. (2001). Since the purpose of modeling in this study was limited to determining the changes in $\triangle \mathrm{ANC}_{(\mathrm{poll}, t)}$ during runoff episodes, it was not necessary to satisfy all of the assumptions made when modeling natural $\mathrm{pH}$ declines in the original BDM (Bishop et al., 2000). However, one assumption that must be fulfilled in this use of BDM is that the sum of base cations can be used as a surrogate for the natural dilution of ANC, as discussed in more detail by Laudon et al. (2001).

Trends in the anthropogenic component of episodic ANC declines were analysed using the non-parametric Kendall tau (Systat version 14) to identify monotonic long-term trends (Yue et al., 2002). The significance level of the statistical analyses was set to be significant when the p-value was $<0.05$.

\section{Results}

In total 342 episodes were identified using the hydrological definition of a 10-fold increase in discharge from baseflow to peak flow. The number of identified episodes affecting each stream varied between ten and 28 . Of the
25 sampled streams, ten displayed a decreasing trend in $\triangle \mathrm{ANC}_{(\text {poll })}(\mathrm{p}<0.05)$ over the study period (Table 1$)$, hereafter termed "recovering" streams. Nine of these ten recovering streams are located in southern Sweden and one in central Sweden; no stream in northern Sweden showed a decreasing trend. Of the recovering streams in southern Sweden most were located relatively far from the Atlantic coast. The mean annual $\mathrm{Cl}^{-}$stream water concentration (average $185 \mu \mathrm{eq} \mathrm{L}{ }^{-1}$; standard deviation $66 \mu \mathrm{eq} \mathrm{L}{ }^{-1}$ ) was also significantly lower $(\mathrm{p}<0.01$; one way ANOVA) than in the non-recovering streams (average $271 \mu \mathrm{eq} \mathrm{L} \mathrm{L}^{-1}$; standard deviation $43 \mu \mathrm{eq} \mathrm{L}^{-1}$ Table 2, Fig. 2). No correlation ( $\mathrm{p}>0.1$; one way ANOVA) was found between recovering streams and any other stream chemical parameter tested including all other major an- and base cations. Furthermore, no correlations ( $p>0.1$; one way ANOVA) were found between the recovering streams and either sulfur or nitrogen deposition in any of the regions.

Most streams displayed a clear relationship between episodic response and antecedent runoff (Fig. 3). In southern Sweden $\triangle \mathrm{ANC}_{(\text {poll) }}$ was logarithmically correlated $(\mathrm{p}<0.05)$ to antecedent discharge in 11 of the 16 studied streams (Table 1). The lowest antecedent discharge resulted in ANC declines of over $500 \mu \mathrm{eq} \mathrm{L}^{-1}$ in some instances driven mainly by increases in $\mathrm{SO}_{4}^{2-}$ concentration. In central Sweden all of the studied streams showed a significant relationship, but the two variables were significantly correlated for only one of the five studied streams in northern Sweden. In all streams $\mathrm{SO}_{4}^{2-}$ was the most important driving variable for changes in $\triangle \mathrm{ANC}_{(\text {poll })}$ although both $\mathrm{BC}$ dilution and $\mathrm{NO}_{3}^{-}$influenced the ANC decline during occasional episodes. The role of $\mathrm{SO}_{4}^{2-}$ concentration driving the ANC decline was especially prominent when drought conditions where preceding the episode. At wetter conditions $\mathrm{BC}$ dilution played a larger role in depressing $\mathrm{ANC}$, whereas $\mathrm{NO}_{3}^{-}$showed a more stochastic influence the ANC decline during episodes.

\section{Discussion}

Generally most surface waters in Sweden have shown a significant decline in stream water $\mathrm{SO}_{4}^{2-}$ concentrations, associated with the long-term decline in anthropogenic acid deposition, during the last decades (Fölster et al., 2003; Fölster and Wilander, 2002). However, these reductions in stream water $\mathrm{SO}_{4}^{2-}$ concentrations are often offset during high runoff by pulses of $\mathrm{SO}_{4}^{2-}$ from episodically activated flow pathways. Such offsets are especially pronounced during high sea-salt episodes and by preceding drought conditions, which cause transient increases in anthropogenically derived $\mathrm{H}^{+}$and labile inorganic aluminum $\left(\mathrm{Al}_{i}\right)$ concentrations, with associated effects on the stream water ANC and $\mathrm{pH}$.

Deposition of marine base cations can cause transient seasalt related acidification episodes (Heath et al., 1992). Such episodes have been reported to cause severe fish kills in 
Table 2. Summary of average stream chemistry.

\begin{tabular}{|c|c|c|c|c|c|c|c|c|}
\hline Stream & $\mathrm{pH}$ & $\begin{array}{c}\mathrm{SO}_{4} \\
\mu \mathrm{eq} / 1\end{array}$ & $\begin{array}{c}\mathrm{Cl} \\
\mu \mathrm{eq} / 1\end{array}$ & $\begin{array}{l}\mathrm{NO}_{3} \\
\mu \mathrm{eq} / 1\end{array}$ & $\begin{array}{c}\mathrm{Ca} \\
\mu \mathrm{eq} / 1\end{array}$ & $\begin{array}{c}\mathrm{Mg} \\
\mu \mathrm{eq} / 1\end{array}$ & $\begin{array}{c}\mathrm{Na} \\
\mu \mathrm{eq} / 1\end{array}$ & $\begin{array}{c}\mathrm{K} \\
\mu \mathrm{eq} / \mathrm{l}\end{array}$ \\
\hline \multicolumn{9}{|l|}{ Southern Sweden } \\
\hline G1 (4) & 4.99 & 170 & 169 & 1 & 151 & 101 & 200 & 10 \\
\hline G2 (4) & 4.70 & 175 & 176 & 0 & 166 & 106 & 189 & 7 \\
\hline G2 (4R) & 4.48 & 176 & 179 & 1 & 103 & 88 & 196 & 9 \\
\hline $\mathrm{K} 2$ (4) & 4.44 & 354 & 205 & 12 & 272 & 124 & 246 & 23 \\
\hline L1 (4) & 4.74 & 320 & 346 & 7 & 202 & 155 & 385 & 15 \\
\hline L2 (4) & 4.32 & 350 & 264 & 5 & 169 & 105 & 271 & 7 \\
\hline $\mathrm{O} 2(4)$ & 4.35 & 157 & 302 & 3 & 60 & 77 & 295 & 8 \\
\hline N1 (4) & 5.18 & 214 & 312 & 11 & 181 & 128 & 286 & 13 \\
\hline P1 (4) & 4.99 & 166 & 275 & 4 & 122 & 73 & 266 & 7 \\
\hline P2 (4) & 4.99 & 163 & 202 & 2 & 113 & 80 & 210 & 7 \\
\hline P3 (4A) & 4.61 & 229 & 146 & 41 & 88 & 62 & 123 & 28 \\
\hline P3 (4B) & 4.73 & 191 & 167 & 25 & 158 & 62 & 141 & 24 \\
\hline R2 (4) & 5.40 & 182 & 208 & 2 & 269 & 101 & 225 & 11 \\
\hline Berg (Pipbäcken N) & 4.58 & 158 & 294 & 1 & 87 & 98 & 274 & 8 \\
\hline Berg (Pipbäcken Ö) & 4.42 & 132 & 286 & 1 & 67 & 83 & 259 & 8 \\
\hline Tostarp & 6.00 & 374 & 295 & 14 & 352 & 213 & 322 & 17 \\
\hline \multicolumn{9}{|l|}{ Central Sweden } \\
\hline Tresticklan & 4.44 & 89 & 161 & 1 & 50 & 45 & 163 & 9 \\
\hline Tiveden (Bråtäng) & 4.60 & 124 & 96 & 1 & 90 & 51 & 117 & 9 \\
\hline Tiveden (Lomma N) & 4.30 & 124 & 89 & 0 & 56 & 41 & 111 & 7 \\
\hline Tiveden (Lomma Ö) & 4.28 & 156 & 98 & 1 & 69 & 50 & 118 & 7 \\
\hline \multicolumn{9}{|l|}{ Northern Sweden } \\
\hline Tandövalen & 4.67 & 52 & 18 & 1 & 28 & 15 & 39 & 4 \\
\hline Stormyran & 6.31 & 36 & 21 & 2 & 120 & 116 & 48 & 7 \\
\hline Sandnäset & 6.64 & 293 & 81 & 2 & 175 & 53 & 83 & 9 \\
\hline Ammarnäs & 6.92 & 49 & 42 & 1 & 284 & 67 & 58 & 25 \\
\hline Reivo & 6.78 & 29 & 14 & 2 & 112 & 34 & 58 & 8 \\
\hline
\end{tabular}

coastal rivers (Hindar et al., 1994). The clear difference in recovery of $\triangle \mathrm{ANC}_{\text {(poll) }}$ found in this study between inland and coastal streams (with low $\mathrm{Cl}^{-}$and high $\mathrm{Cl}^{-}$concentrations, respectively) in southern Sweden indicates that sea-salt deposition has an influence not only on the effects of individual episodes, but also on the cumulative effects of episodic acidification in the longer-term. Sea-salt deposition is generally regarded as being highly stochastic, primarily occurring in short, intense events that cause transient, episodic declines in both and $\mathrm{pH}$ and ANC. However, the deposition of marine ions in coastal sites can also be described as a continuum of high sea-salt deposition that continuously affect soil and stream water chemistry in some regions (Evans et al., 2001). This suggests that sea-salt does not solely have transient, short-term influences, but could also have more longterm effects on surface water chemistry due to the continuous addition of marine base cations in some coastal regions.

The main influence of sea-salt on stream water ANC is due to the exchange of marine base cations, primarily sodium $\left(\mathrm{Na}^{+}\right)$, with adsorbed acid cations, hydrogen $\left(\mathrm{H}^{+}\right)$and labile inorganic aluminum $\left(\mathrm{Al}_{i}\right)$, in the soil. Hence, contin- uous low doses of marine base cations, spiked with occasional high doses, could retard the episodic recovery. Seasalt induced hydrochemical episodes have also been linked to decadal cycles of storm intensities driven by the North Atlantic Oscillation (NAO) (Hindar et al., 2004). This pattern of short-term variability in sea-salt deposition superimposed on more long-term cycles makes it difficult to disentangle trends in episodic response from natural variability. Indeed, the strong but intermittent marine influence in many coastal regions could explain why coastal catchments with relatively high stream water $\mathrm{Cl}^{-}$concentrations are not recovering to the same degree as streams further inland.

The strong correlation between episodic responses and antecedent runoff (which may be considered a surrogate for soil wetness) suggests that re-oxidation of sulfur in catchment soils is an important factor affecting hydrochemical responses during episodes. Reports from acidified regions in both Europe and North America have shown that reoxidation of previously water-logged organic soil leads to pulses of acidic, $\mathrm{SO}_{4}^{2-}$-rich water that may have a dramatic influence on stream ANC and pH during episodes (Schiff et 

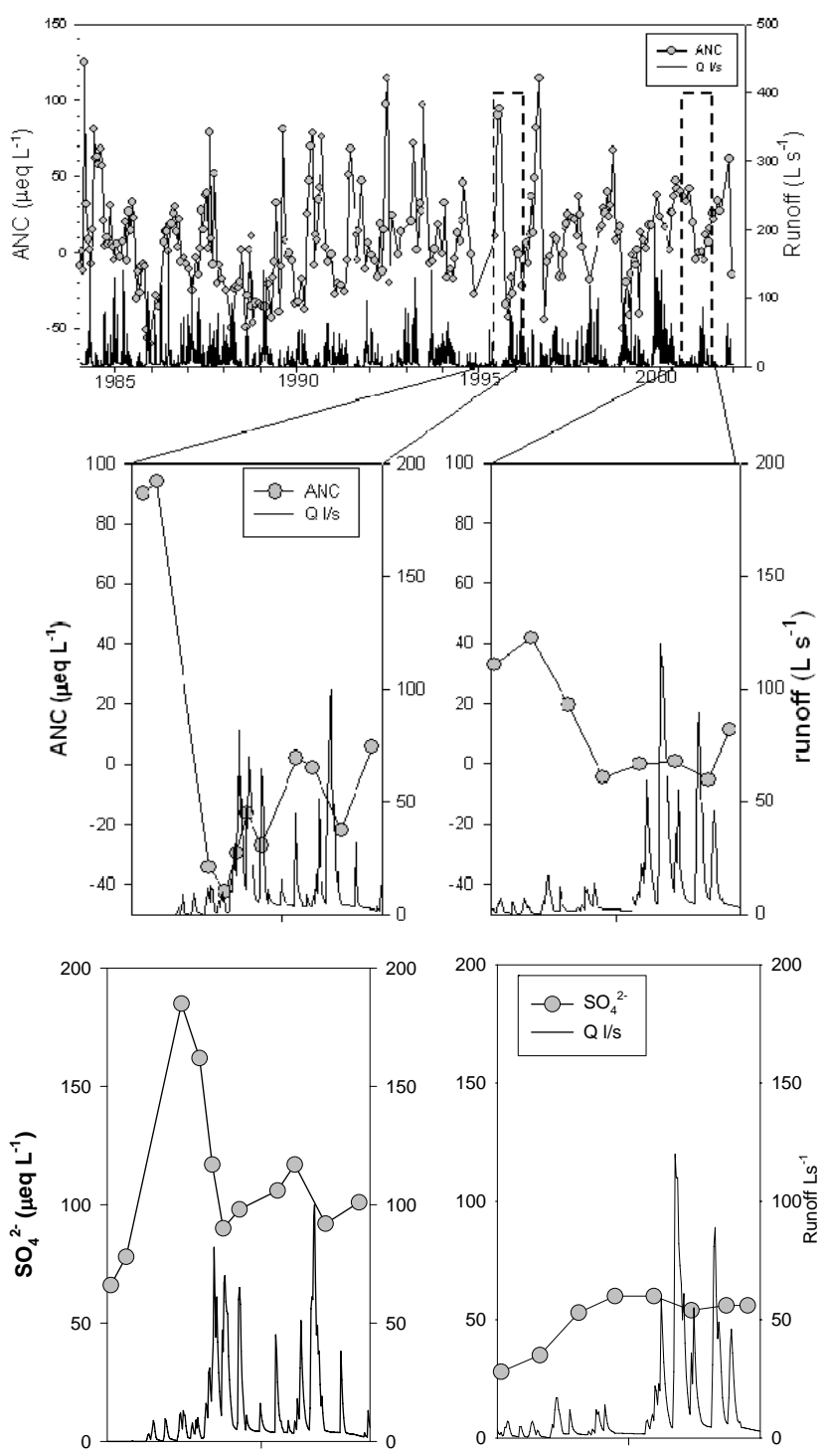

Fig. 3. (a) Time series of ANC variability from 1985-2002 in Tresticklan (above) with examples of episodic ANC response with dry antecedent conditions (below left) and wet antecedent conditions (below right). (b) The accompanied $\mathrm{SO}_{4}$ response to the dry antecedent conditions (left) and wet antecedent conditions (right).

al., 2005; Laudon et al., 2004). The strong correlation between $\triangle \mathrm{ANC}_{(\text {poll) }}$ and antecedent discharge found for most of the streams included in this study also suggests that the largest anthropogenic component of the episodic acidification is associated with preceding drought conditions. These results have important implications for predictions of acidification recovery in the future, especially in regions where climate scenarios forecast that conditions are likely to become warmer and drier.

The rapid release of sulfate associated with drought is clearly not primarily caused by the most recent deposition of atmospheric sulfur. Recent trend analyses in Canada

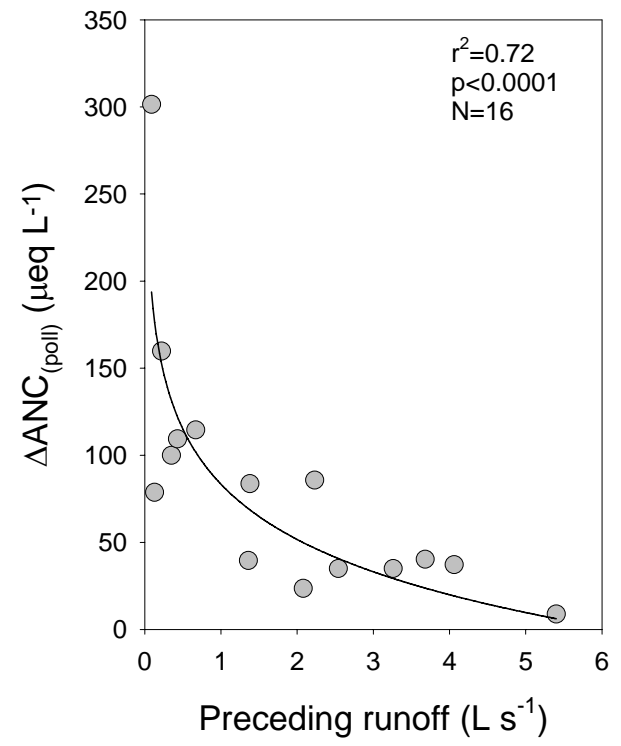

Fig. 4. Correlation between antecedent runoff and anthropogenic response $\left(\triangle \mathrm{ANC}_{(\text {poll })}\right)$ during episodes in one of the study streams (P1 (4)). The remaining p-values of the correlation are given in Table 1.

have demonstrated that long-term or multi-season droughtinduced $\mathrm{SO}_{4}$ mobilization retards general recovery from acidification (Eimers et al., 2004b; Jeffries et al., 2002). Hence, a possible explanation for the strong correlation between low antecedent runoff and the anthropogenically driven $\triangle \mathrm{ANC}_{\text {(poll) }}$ found in this study is that a temporary lowering of the ground water level can result in a transformation of immobile sulfides to readily mobile sulfates that can be washed out during subsequent hydrological episodes. In support of this hypothesis, it has been found that mineralization of organic sulfur compounds in organic soils can be an important mechanism in generating sulfate-rich pulses which, temporarily at least, transform some catchments from sinks to sources of stream water sulfate (Alewell et al., 1999). In a recent study by Laudon et al. (2004) in central Canada the areal coverage of wetlands also showed to be a good predictor of the size of the anthropogenic acidity pulse following drought. However, no information of the amount of organic soils or wetland coverage is available for the streams reported on here.

In many of the streams included in this study, especially those in the inland sites, the negative effects of episodic acidification events on ANC are correlated with stream water sulfate concentrations in the region (Fölster et al., 2003; Fölster and Wilander, 2002), indicating that the magnitude of sulfate pulses during droughts depend on the size and lability of the sulfur pools remaining in the catchments' soils. This suggests that the magnitude of drought-induced sulfate pulses in the future will primarily be determined by the source depletion rate together with the rate of sulfate pool reloading 
by future deposition. Therefore, despite a likely continuation of emission reductions in Europe drought-induced sulfate episodes may continue to cause extreme values of $\triangle \mathrm{ANC}_{(\text {poll })}$ in some streams in the future.

Regional climate models predict that further increases in temperature will occur in Sweden during the coming decades, accompanied by reductions in summer precipitation and more frequent storms during the fall and winter in large areas of the country (Kjellström, 2004). If these predictions are realized, the effects of episodic acidification in many Swedish streams may be prolonged and aggravated by increases in the frequency and intensity of droughts and seasalt episodes.

\section{Conclusion}

The anthropogenic contribution to the declines in ANC observed during rain episodes in Sweden often follow periods of drought. This phenomenon is especially prominent in southern and central Sweden; regions that have been subject to high levels of acid deposition historically. However, these streams are generally found in inland regions, where the long-term effects of the decline in anthropogenic acidification are ameliorating the effects. In coastal areas, high deposition of sea-salt appears to be retarding the episodic recovery in many streams.

Acknowledgements. Funding for this research was provided by a grant from the Swedish Environmental Protection Agency. Many thanks are due to the late $\mathrm{O}$. Westling, who was involved in an early stage of this project.

Edited by: P. Dillon and R. F. Wright

\section{References}

Alewell, C., Mitchell, M. J., Likens, G. E., and Krouse, H. R.: Sources of stream sulfate at the Hubbard Brook Experimental Forest: Long-term analyses using stable isotopes, Biogeochemistry, 44, 281-299, 1999.

Baker, J. P., VanSickle, J., Gagen, C. J., DeWalle, D. R., Sharpe, W. E., Carline, R. F., Baldigo, B. P., Murdoch, P. S., Bath, D. W., Kretser, W. A., Simonin, H. A., and Wigington, P. J.: Episodic acidification of small streams in the northeastern United States: Effects on fish populations, Ecol. Appl., 6, 422-437, 1996.

Bishop, K. H., Laudon, H., and Köhler, S.: Separating the natural and anthropogenic components of spring flood $\mathrm{pH}$ decline: A method for areas that are not chronically acidified, Water Resour. Res., 30, 1873-1889, 2000.

Christophersen, N., Dymbe, L. H., Johannssen, M., and Seip, H. M.: A Model for Sulphate in Streamwater at Stogama, Southern Norway, Ecol. Model., 21, 35-61, 1983.

Devito, K. J., Hill, A. R., and Dillon, P. J.: Episodic sulphate export from wetlands in acidified headwater catchments: prediction at the landscape scale, Biogeochemistry, 44, 187-203, 1999.
Eimers, M. C., Dillon, P. J., and Schiff, S. L.: Sulphate flux from an upland forested catchment in South-Central Ontario, Canada, Water Air Soil Poll., 152, 3-21, 2004a.

Eimers, M. C., Dillon, P. J., and Watmough, S. A.: Long-term (18year) changes in sulphate concentrations in two Ontario headwater lakes and their inflows in response to decreasing deposition and climate variations, Hydrol. Process., 18, 2617-2630, $2004 \mathrm{~b}$.

Evans, C. D., Monteith, D. T., and Harriman, R.: Long-term variability in the deposition of marine ions at west coast sites in the UK Acid Waters Monitoring Network: impacts on surface water chemistry and significance for trend determination, Sci. Total Environ., 265, 115-129, 2001.

Fölster, J., Bishop, K., Kram, P., Kvarnas, H., and Wilander, A.: Time series of long-term annual fluxes in the streamwater of nine forest catchments from the Swedish environmental monitoring program (PMK 5), Sci. Total Environ., 310, 113-120, 2003.

Fölster, J. and Wilander, A.: Recovery from acidification in Swedish forest streams, Environ. Pollut., 117, 379-389, 2002.

Heath, R. H., Kahl, J. S., Norton, S. A., and Fernandez, I. J.: Episodic stream acidification caused by atmospheric deposition of sea salts at Acadia National Park, Maine, United States, Water Resour. Res., 28, 1081-1088, 1992.

Hindar, A., Henrikssen, A., Torseth, K., and Semb, A.: Acid water and fish death, Nature, 372, 327-328, 1994.

Hindar, A., Torseth, K., Henriksen, A., and Orsolini, Y.: The significance of the North Atlantic Oscillation (NAO) for sea-salt episodes and acidification-related effects in Norwegian rivers, Environ. Sci. Technol., 38, 26-33, 2004.

Jeffries, D. S., Semkin, R. G., Beall, F. D., and Franklyn, J.: Temporal trends in water chemistry in the Turkey Lakes watershed, Ontario, Canada, 1982-1999, Water Air Soil Poll., Focus, 2, 5$22,2002$.

Kindbom, K., Sjöberg, K., Munthe, J., Peterson, K., Persson, C., Roos, E., and Bergström, R.: Nationell miljöövervakning av nederbördskemi, IVL (Swedish Environmental Research Institute), 35 pp., (in Swedish), 1998.

Kjellström, E.: Recent and future signatures of climate change in Europe. Ambio, 33, 193-198, 2004.

Kowalik, R. A. and Ormerod, S. J.: Intensive sampling and transplantation experiments reveal continued effects of episodic acidification on sensitive stream invertebrates, Freshwater Biol., 51, 180-191, 2006.

Laudon, H. and Bishop, K.: Episodic stream water decline during autumn storms following a summer drought, Hydrol. Process., 16, 1725-1733, 2002.

Laudon, H., Clair, T. A., and Hemond, H. F.: Long-term response in episodic acidification to declining SO42- deposition in two streams in Nova Scotia, Hydrol. Earth Syst. Sci., 6, 773-781, 2002 , http://www.hydrol-earth-syst-sci.net/6/773/2002/.

Laudon, H., Dillon, P. J., Eimers, M. C., Semkin, R. G., and Jeffries, D. S.: Climate-induced episodic acidification of streams in central Ontario, Environ. Sci. Technol., 38, 6009-6015, 2004.

Laudon, H. and Hemond, H. F.: Recovery of streams from episodic acidification in northern Sweden, Environ. Sci. Technol., 36, 921-928, 2002.

Laudon, H., Westling, O., Lofgren, S., and Bishop, K.: Modeling preindustrial $\mathrm{ANC}$ and $\mathrm{pH}$ during the spring flood in northern Sweden, Biogeochemistry, 54, 171-195, 2001. 
Lawrence, G. B.: Persistent episodic acidification of streams linked to acid rain effects on soil, Atmos. Environ., 36, 1589-1598, 2002.

Lepori, F., Barbieri, A., and Ormerod, S. J.: Effects of episodic acidification on macroinvertebrate assemblages in Swiss Alpine streams, Freshwater Biol., 48, 1873-1885, 2003.

Mylona, S.: Sulphur dioxide emissions in Europe 1880-1991 and their effect on sulphur concentrations and depositions, Tellus B, 48, 662-689, 1996.

Neal, C. and Kirchner, J. W.: Sodium and chloride levels in rainfall, mist, streamwater and groundwater at the Plynlimon catchments, mid-Wales: inferences on hydrological and chemical controls, Hydrol. Earth Syst. Sci., 4, 295-310, 2000, http://www.hydrol-earth-syst-sci.net/4/295/2000/.

Posch, M., Hettelingh, J.-P., de Smet, P. A. M., and Downing, R. T.: Calculation and mapping of critical thresholds in Europe: Status Report 1997, 259101007, RIVM, 1997.

Raddum, G. G., Fjellheim, A., and Skjelkvale, B. L.: Improvements in water quality and aquatic ecosystems due to reduction in sulphur deposition in Norway, Water Air Soil Pollut., 130, 87-98, 2001.

Schiff, S. L., Spoelstra, J., Semkin, R. G., and Jeffries, D. S.: Drought induced pulses of SO42- from a Canadian shield wetland: use of delta S-34 and delta O-18 in SO42- to determine sources of sulfur, Appl. Geochem., 20, 691-700, 2005.

Skjelkvåle, B. L., Mannio, J., Wilander, A., and Andersen, T.: Recovery from acidification of lakes in Finland, Norway and Sweden 1990-1999, Hydrol. Earth Syst. Sci., 5, 327-337, 2001, http://www.hydrol-earth-syst-sci.net/5/327/2001/.
Stoddard, J. L., Jeffries, D. S., Lukewille, A., Clair, T. A., Dillon, P. J., Driscoll, C. T., Forsius, M., Johannessen, M., Kahl, J. S., Kellogg, J. H., Kemp, A., Mannio, J., Monteith, D. T., Murdoch, P. S., Patrick, S., Rebsdorf, A., Skjelkvåle, B. L., Stainton, M. P., Traaen, T., van Dam, H., Webster, K. E., Wieting, J., and Wilander, A.: Regional trends in aquatic recovery from acidification in North America and Europe, Nature, 401, 575-578, 1999.

Warfvinge, P. and Bertills, U.: Recovery from Acidification, Swedish Environmental Protection Agency report 5034, Stockholm, 96 pp., 2000.

Wigington, P. J., Baker, J. P., DeWalle, D. R., Kretser, W. A., Murdoch, P. S., Simonin, H. A., VanSickle, J., McDowell, M. K., Peck, D. V., and Barchet, W. R.: Episodic acidification of small streams in the northeastern United States: Episodic Response Project, Ecol. Appl. Issn, 6, 374-388, 1996.

Wilander, A., Johnson, R. K., Goedkoop, W., and Lundin, L.: Riksinventeringen 1995, Swedish Environmental Protection Agency report 4813, Stockholm, 210 pp., (in Swedish with English summary), 1998.

Yan, N. D., Girard, R., Heneberry, J. H., Keller, W. B., Gunn, J. M., and Dillon, P. J.: Recovery of copepod, but not cladoceran, zooplankton from severe and chronic effects of multiple stressors, Ecol. Lett., 7, 452-460, 2004.

Yue, S., Pilon, P., and Cavadias, G.: Power of the Mann-Kendall and Spearman's rho tests for detecting monotonic trends in hydrological series, J. Hydrol., 259, 254-271, 2002. 